\title{
The Wreckage of Endowed Chairs
}

\section{Daniel Pipes}

For some years, select historians have bemoaned the direction of their discipline. They regret the turn away from war, diplomacy, economics, and ideas in favor of gender, environment, race, and sexuality, as they bemoan the decline in student interest. Niall Ferguson titled his critique "The Decline and Fall of History.” Hal Brands and Francis J. Gavin wrote “The Historical Profession Is Committing Slow-Motion Suicide.” The Economist announced, “The study of history is in decline in Britain." ${ }^{1}$

While the glittery allure of fashionable topics and social-justice grouphugs drive this trend, a less visible economic factor enables it: many university-based historians have no need to attract students or readers. Assured funding from endowed chairs liberates them from having to address anyone other than fellow professional historians. Deans do not demand they fill classrooms; spouses do not clamor for royalties.

The Department of History at Harvard University serves as my example, partly because of its exceptional affluence, partly because of a long association with it (Richard Pipes, my father, first studied there in 1946 and taught there for half a century; I followed in 1967).

The department's website lists fifty faculty. Of these, ten are plain assistant, associate, or full professors without a named chair; thirty-five are associated with one named chair; four with two named chairs; and one with three. (That last is Maya Jasanoff, simultaneously the X.D. and Nancy Yang Professor, Coolidge Professor of History, and Harvard College Professor. Jasanoff emulates the late sultan of Oman, for he served as prime minister, minister of defense,

1 Niall Ferguson, "The Decline and Fall of History," Philip Merrill Award for Outstanding Contributions to Liberal Education, Washington D.C., October 28, 2016; Hal Brands, Francis J. Gavin, "The Historical Profession is Committing Slow-Motion Suicide," Warontherocks.com, December 10, 2018; "The Study of History is in Decline in Britain," The Economist, July 20, 2019.

Daniel Pipes is president of the Middle East Forum and founder of Campus Watch: DanielPipes.org, @ DanielPipes, daniel.pipes@gmail.com. Pipes has an A.B. and a Ph.D. in history, both from Harvard. His last article for Academic Questions, "Anticipating Academia's Decline Already in 1971," appeared in the Summer 2021 issue of $A Q$. 
foreign affairs and finance, and supreme commander of the armed forces and police.)

In fractions, 20 percent of Harvard's historians are plain vanilla, 70 percent fill one endowed chair, 8 percent fill two chairs, and 2 percent fill three chairs. In functional terms, four-fifths of the departmental faculty enjoys an assured career-long income without the need to attract a single student or reader.

This is no longer the ivory tower but the ivory tower on steroids. Endowed professors benefit not only from the standard privileges of tenure (i.e., assured employment until retirement) and academic freedom of speech (the privilege to spout off with impunity about anything not politically incorrect), but they are also uniquely insulated from economic worries by virtue of a dedicated trust fund paying their salaries. (In 2019, Harvard paid an average salary of $\$ 226,000$ to professors, with named professors making substantially more.)

Such liberation opens the way to eccentricity. In 2016, Harvard offered a course on "Emotions in History: Issues, Approaches and Cases" which promised to study "how to write the history of emotion(s), and how the historian's emotions affect the writing of history." The past year's offerings included "The Game: College Sports as History,” “Abolition Ecologies: Nature, Race, and Labor in the United States," and two narrowly self-indulgent courses, "Harvard and Slavery” and "Intro to Harvard History: Beyond the Three Lies."

The latter, taught by Zach Nowak, with the cute designation History 1636 (the year of Harvard's founding), promises to "change the way you see Harvard." Nowak explains:

Harvard's history is a story of professors, students, courses, and research that has led to world-changing innovations. But it is also a story of student unrest, gender unease, and the exclusion of women and minorities, enslaved people, Native Americans, and working-class people. All of them made Harvard and left traces in its archives, libraries, and museums, its buildings, and even in its soil. Some Harvard stories have been told; others have been forgotten. In this class, we will uncover Harvard's past. There will be several field trips to Harvard's archives and museums and other places on campus most students will never visit. 
Nowak sweetens the ironic attraction of his course by adding, "If you wish, the [Harvard] University Archives will preserve your final paper on Harvard history for perpetuity."

By skillfully isolating themselves from the despised capitalist system that created the wealth they enjoy, these professors find themselves free to ignore the great issues of the age and to dwell instead on voguish topics of the moment.

Thus does too much money impede the study of history, by transforming modest scholars into endowed and titled academicians while simultaneously removing the need for them to appeal to an audience. Well-meaning donors have facilitated the race to pomposity and triviality. Do they want this outcome? If not, will they wake to their errors? 